\title{
The Role of Menaquinone and $b$-Type Cytochrome in Anaerobic Reduction of Fumarate by NADH in Membrane Preparations from Bacteroides ruminicola Strain $B_{1} 4$
}

\author{
By D. O. MOUNTFORT* AND A. M. ROBERTON \\ Department of Biochemistry, University of Auckland, Private Bag, \\ Auckland, New Zealand
}

(Received 29 December 1976)

\begin{abstract}
SUMMARY
The electron transfer system catalysing reduction of fumarate by NADH under anaerobic conditions in membrane preparations of Bacteroides ruminicola strain $\mathrm{B}_{1} 4$ was inhibited by 2 -n-heptyl-4-hydroxyquinoline $N$-oxide. Reduction of $b$-type cytochrome by NADH under anaerobic conditions was much slower than reduction of fumarate by NADH, and was more sensitive to 2-n-heptyl-4-hydroxyquinoline $N$-oxide inhibition. Thus $b$-type cytochrome is probably not an intermediate in the reduction of fumarate by NADH under the in vitro assay conditions used. Extraction of quinone from the membrane and subsequent reincorporation showed that menaquinone (vitamin $\mathrm{K}_{2}$ ) is an obligatory intermediate in the reduction of both fumarate and $b$-type cytochrome by NADH, which is consistent with the 2-n-heptyl4-hydroxyquinoline $N$-oxide inhibition results. A tentative scheme for electron transport in $B$. ruminicola is presented.
\end{abstract}

\section{INTRODUCTION}

The strict anaerobe Bacteroides ruminicola is one of the more numerous fermenters of carbohydrate in the rumen (Bryant et al., 1958) where it successfully flourishes in competition with many other organisms. Growth on glucose in vitro gives a high molar growth yield of $66 \mathrm{~g}$ dry wt per mol glucose (Howlett et al., 1976), suggesting either that the ATP molar growth yield is much greater than the normal value of about $10.5 \mathrm{~g}$ dry wt per mol ATP, or that anaerobic electron transport is coupled to phosphorylation, or that both these possibilities occur. Indeed $B$. ruminicola contains $b$-type cytochrome and flavoprotein(s) which it has been suggested are involved in fumarate reduction by donor substrates (White, Bryant \& Caldwell, 1962).

Many of the above properties have also been observed in a number of other anaerobes producing succinate or propionate [see Macy, Probst \& Gottschalk (I975) for a summary], so the question of whether anaerobic electron transport phosphorylation occurs in $B$. ruminicola has a broad significance. We have studied the electron transfer chain of $B$. ruminicola to gain a better understanding of the postulated role of $b$-type cytochrome and the possible participation of quinone in the membrane-associated reduction of fumarate by NADH in this organism. In accordance with the majority of recent studies, we used membrane preparations rather than the intact bacteria used by White et al. (I962).

\footnotetext{
* Present address: Cawthron Institute, P.O. Box I75, Nelson, New Zealand.
} 


\section{METHODS}

Bacteria. Bacteroides ruminicola, strain $\mathrm{B}_{1} 4$, was maintained and grown in 51 batches as previously described (Howlett et al., 1976) with $0.2 \%$ (w/v) glucose as energy source. Bacteria were harvested at full growth by centrifuging for $20 \mathrm{~min}$ at $5000 \mathrm{~g}$.

Preparation of membrane particles. Membranes were prepared by a method based on that of Broberg \& Smith (1967) with the oxygen tension kept as low as possible throughout. A solution $\left(20 \mathrm{ml}\right.$ ) containing $0.5 \mathrm{M}$-sucrose, $0.02 \mathrm{M}-\mathrm{MgCl}_{2}$ and $0.0 \mathrm{I} \mathrm{M}$-phosphate buffer $\mathrm{pH} 7 \cdot 0$ was deoxygenated by evacuation followed by gassing with $\mathrm{N}_{2}$, and then $5 \mathrm{~g}$ wet wt bacteria and $3 \mathrm{mg}$ lysozyme (Sigma, grade I) were added. This suspension was incubated at $25{ }^{\circ} \mathrm{C}$ under $\mathrm{N}_{2}$ until the cells became sphaeroplasts. The sphaeroplasts were separated by centrifuging at $9000 \mathrm{~g}$ for $\mathrm{I} 5 \mathrm{~min}$, and then suspended in $50 \mathrm{ml}$ deoxygenated $0.0 \mathrm{I} \mathrm{M}$ phosphate buffer $\mathrm{pH} 7{ }^{\circ}$, containing $40 \mu \mathrm{g}$ DNAase (Worthington Biochemical Corp.). The suspension was stirred under $\mathrm{N}_{2}$ and when $90 \%$ of the sphaeroplasts had lysed it was centrifuged at $33000 \mathrm{~g}$ for $30 \mathrm{~min}$. The membrane particles, which formed a white fluffy layer on top of the cell wall pellet, were suspended in an appropriate volume of $50 \mathrm{~mm}-\mathrm{Tris} / \mathrm{HCl}$ buffer, $\mathrm{pH} 7 \cdot 0$, degassed under $\mathrm{N}_{2}$, and either used immediately or quickly frozen in solid $\mathrm{CO}_{2} /$ ethanol and stored at $-5{ }^{\circ} \mathrm{C}$. Alternatively, when the membrane particles were to be used in quinone-depletion studies, they were suspended in $0.15 \mathrm{M}-\mathrm{KCl}$, freeze-dried by lyophilization for $12 \mathrm{~h}$ and stored in vacuum over $\mathrm{P}_{2} \mathrm{O}_{5}$.

Protein measurement. Protein was determined by the biuret method (Gornall, Bardawill \& David, I949) using $0.15 \mathrm{ml}$ of $\mathrm{I} .5 \%(\mathrm{w} / \mathrm{v})$ sodium deoxycholate per $3 \mathrm{ml}$ final volume to solubilize the membrane protein. Bovine serum albumin (fraction V) was used as the standard.

Solvent extraction of membrane particles. Two methods were used. During studies to identify and quantify quinone, membranes were shaken with methanol/acetone and extracted with light petroleum (b.p. 40 to $60^{\circ} \mathrm{C}$ ) as described by Kroger \& Dadak (1969). For enzyme studies on the effects of removing and subsequently reincorporating quinone, the method of Kroger et al. (197I) was used, involving extraction of lyophilized membrane particles six times with n-pentane.

Reincorporation of vitamin $K$ into depleted particles. One $\mu$ mol of vitamin $\mathrm{K}_{1}$, or of quinone extracted from $B$. ruminicola membranes, was dissolved in $1.5 \mathrm{ml}$ pentane, homogenized with approximately $20 \mathrm{mg}$ of pentane-extracted particles at $0^{\circ} \mathrm{C}$ and shaken for $30 \mathrm{~min}$. The 'reincorporated' particles were centrifuged at $2000 \mathrm{~g}$ for $2 \mathrm{~min}$ at $0^{\circ} \mathrm{C}$, the pentane supernatant fluid was discarded and the particles were washed gently with a minimum volume of pentane to remove excess quinone. The pentane was decanted and the particles were suspended in $0.25 \mathrm{M}$-sucrose (Ernster et al., I969). 'Reincorporated' particles were used immediately for assays.

Spectrophotometric measurement of quinone content. This was carried out using a dualbeam Cary II8C spectrophotometer. To the sample cuvette were added $3 \mathrm{ml}$ of quinone extract in ethanol, $50 \mu \mathrm{l} \mathrm{NaBH}_{4}$ solution $\left(5 \mathrm{mg} \mathrm{ml}^{-1}\right)$ and $20 \mu \mathrm{l} 0.4 \mathrm{M}$-sodium acetate pH 5.4. Quinone and buffer only were added to the control cuvette. A difference spectrum was recorded between 300 and $230 \mathrm{~nm}$. The concentration of menaquinone was calculated from the molar difference extinction coefficient at $265 \mathrm{~nm}$ minus $289 \mathrm{~nm}\left(E_{\text {red }}-E_{\text {ox }}\right)_{265 \mathrm{~nm}}-$ $\left(E_{\text {red }}-E_{\text {ox }}\right)_{289 \mathrm{~nm}}=14.7 \mathrm{mM}^{-1} \mathrm{~cm}^{-1}$ (Kroger \& Dadak, 1969).

Measurements on b-type cytochrome. All measurements were carried out at $25^{\circ} \mathrm{C}$ in an incubation medium containing about $2 \mathrm{mg}$ membrane protein and reagent A (I00 $\mu \mathrm{mol}$ Tris/ $\mathrm{HCl}$ buffer, $\mathrm{pH} 7 \cdot 5$, containing Io $\mu \mathrm{mol} \mathrm{MgCl}_{2}$ ) in $3 \mathrm{ml}$ final volume. For measurements 
of $b$-type cytochrome concentrations, a few crystals of sodium dithionite were added to the experimental cuvette and $5 \mu \mathrm{mol}$ sodium fumarate to the reference cuvette. A difference spectrum was recorded and the absorbance difference at $561 \mathrm{~nm}$ minus $572 \mathrm{~nm}$ was measured. Cytochrome $b_{1}$ has a difference extinction coefficient $\left(E_{\text {red }}-E_{0 \mathrm{x}}\right)_{557.5 \mathrm{~nm}}-$ $\left(E_{\text {red }}-E_{0 \mathrm{x}}\right)_{575 \mathrm{~nm}}$ of $17.5 \mathrm{~mm}^{-1} \mathrm{~cm}^{-1}$ (Deeb \& Hager, I964; Kroger \& Dadak, 1969). To estimate the concentration of $b$-type cytochrome in $B$. ruminicola it was assumed that the $\alpha$-band difference extinction coefficient at $56 \mathrm{I} \mathrm{nm}$ minus $572 \mathrm{~nm}$ was quantitatively similar to the $\alpha$-band of cytochrome $b_{1}$. (This approximation is necessary until the cytochrome(s) can be purified.)

The redox state of $b$-type cytochrome during anaerobic electron transport was determined from the absorbance difference at $56 \mathrm{I} \mathrm{nm}$ minus $572 \mathrm{~nm}$ in I cm light-path cuvettes, measured using a dual wavelength attachment on the spectrophotometer. The cuvettes, sealed with serum stoppers, were evacuated and then refilled with $\mathrm{O}_{2}$-free $\mathrm{N}_{2}\left(\mathrm{~N}_{2}\right.$ scrubbed free from $\mathrm{O}_{2}$ by passage over hot copper) at least five times before anaerobic addition of the final reagents to initiate the reaction. The incubation mixtures contained about $2 \mathrm{mg}$ membrane protein and reagent $\mathrm{A}$ in $3 \mathrm{ml}$ final volume.

NADH:fumarate oxidoreductase activity. Assays were carried out anaerobically in cuvettes sealed with serum stoppers. Two serum-stoppered reagent bottles containing fumarate and membrane particles respectively and two serum-stoppered cuvettes, containing reagent $A$ and, in the experimental cuvette only, $0.64 \mu \mathrm{mol} \mathrm{NADH}$, were evacuated and refilled at least five times with $\mathrm{O}_{2}$-free $\mathrm{N}_{2}$. Membrane particles ( 0.5 to $1 \cdot 0 \mathrm{mg}$ protein) were injected anaerobically into each cuvette, and NADH oxidation was monitored at $340 \mathrm{~nm}$. NADH oxidase activity was negligible under these conditions. The reaction was then started by injecting fumarate anaerobically into both cuvettes, to give $3.0 \mathrm{ml}$ final volume. Inhibitors, when added, were degassed and injected anaerobically at least $5 \mathrm{~min}$ before addition of fumarate. Assays were carried out at $25^{\circ} \mathrm{C}$.

\section{RESULTS}

\section{NADH:fumarate oxidoreductase activity}

In six separate experiments $\mathrm{NADH}$ :fumarate oxidoreductase activity in $B$. ruminicola membranes was I5 to I $7 \mu \mathrm{mol} \mathrm{NADH}$ min $^{-1}$ (g protein) ${ }^{-1}$ under the assay conditions used. The activity was inhibited by 2-n-heptyl-4-hydroxyquinoline $N$-oxide (HQNO), $2.5 \times 10^{4}$ nmol HQNO (g protein) ${ }^{-1}$ (i.e. $6.5 \mu \mathrm{M}$-HQNO) giving $50 \%$ inhibition (Fig. I). Rotenone, at between $0 . \mathrm{I}$ and $5 \mu \mathrm{M}$, and antimycin $\mathrm{A}$, at between $0 . \mathrm{I}$ and $10 \mu \mathrm{M}$, did not inhibit $\mathrm{NADH}$ : fumarate oxidoreductase activity in membranes, in agreement with the experiments of White et al. (1962) using whole bacteria.

\section{Quinone content of membranes}

The inhibition by HQNO suggested that a quinone may be involved in the NADH: fumarate oxidoreductase reaction (cf. Cox et al., 1970). Accordingly membranes were lyophilized and extracted with methanol/acetone, and a reduced-versus-oxidized difference spectrum of the extract was recorded (Fig. 2). The difference spectrum was similar to that of authentic menaquinone (vitamin $\mathrm{K}_{2}$ ) presented by Kroger \& Dadak (I969). Both spectra had an absorption maximum at $245 \mathrm{~nm}$ and absorption minima at 263 and $272 \mathrm{~nm}$. It is unlikely that the compound from $B$. ruminicola is vitamin $K_{1}$ (phylloquinone) since a sample of vitamin $\mathrm{K}_{1}$ (Sigma) had a difference spectrum maximum at $243 \mathrm{~nm}$ (see also Morton, 1965 ; Crane \& Sun, 1972).

Menaquinone concentrations were determined assuming a difference extinction coefficient 


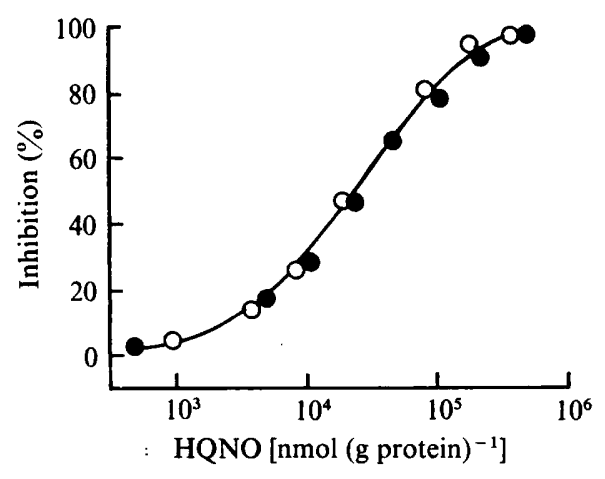

Fig. I

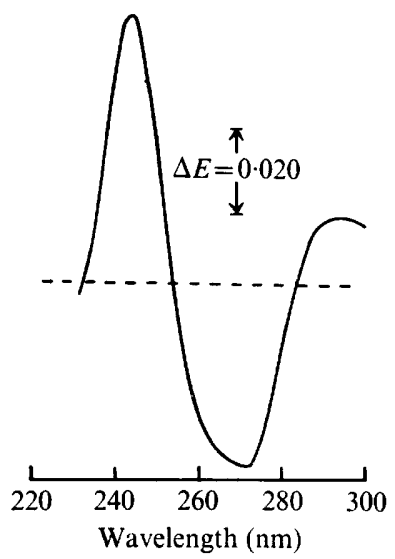

Fig. 2

Fig. I. Inhibition of NADH:fumarate oxidoreductase activity in membranes of $B$. ruminicola by HQNO. Results are shown for two separate experiments in which the membrane particle concentrations were (O) $0.25 \mathrm{mg}$ protein $\mathrm{ml}^{-1}$, and (O) $0.27 \mathrm{mg}$ protein $\mathrm{ml}^{-1}$.

Fig. 2. Difference spectrum of quinone extracted from membrane particles. Quinone was extracted from $17.5 \mathrm{mg}$ membrane protein and dissolved in $10 \mathrm{ml}$ ethanol. Samples $(3 \mathrm{ml})$ were added to two I cm light-path cuvettes; one sample was reduced with $\mathrm{NaBH}_{4}$, the other was left oxidized.

Table I. Effects of extraction with n-pentane and reincorporation of quinone on vitamin $K$ content and NADH: fumarate oxidoreductase activity in membrane particles

Membrane fraction

Unlyophilized

Lyophilized

Extracted

Reincorporated with extracted menaquinone

Reincorporated with vitamin $\mathbf{K}_{\mathbf{1}}$

\begin{tabular}{|c|c|}
\hline $\begin{array}{l}\text { Vitamin K } \\
\text { content } \\
{[\mu \mathrm{mol}} \\
\left.\text { g protein })^{-1}\right]\end{array}$ & $\begin{array}{l}\text { NADH: fumarate } \\
\text { oxidoreductase } \\
\text { activity } \\
{[\mu \text { mol min }} \\
\left.(\mathrm{g} \text { protein })^{-1}\right]\end{array}$ \\
\hline 2.06 & $16 \cdot 0$ \\
\hline $\mathrm{I} \cdot 95$ & 10.6 \\
\hline $0 . I$ & $I \cdot O$ \\
\hline I'7 & 8.6 \\
\hline $\mathbf{I} \cdot \mathbf{2}^{*}$ & \\
\hline
\end{tabular}

* Vitamin $\mathrm{K}_{1}$ was estimated from the absorbance difference at $265 \mathrm{~nm}$ minus $289 \mathrm{~nm}$ between oxidized and reduced samples, assuming a molar difference extinction coefficient of $16.6 \mathrm{~mm}^{-1} \mathrm{~cm}^{-1}$.

(265 nm minus $289 \mathrm{~nm}$ ) of $14 \cdot 7 \mathrm{~mm}^{-1} \mathrm{~cm}^{-1}$. When the menaquinone extracted from $17.5 \mathrm{mg}$ membrane protein was analysed (Fig. 2), the absorbance difference at $265 \mathrm{~nm}$ minus $289 \mathrm{~nm}$ corresponded to $2.06 \mu \mathrm{mol}$ menaquinone ( $\mathrm{g}$ protein) ${ }^{-1}$ in the membrane preparation. When broken sphaeroplasts were centrifuged at $50000 \mathrm{~g}$ for $\mathrm{I} \mathrm{h}$, the menaquinone content of the supernatant fluid was $0.15 \mu \mathrm{mol}$ (g protein) ${ }^{-1}$, showing that most (if not all) of the menaquinone was associated with the membrane.

\section{Role of quinone in NADH:fumarate oxidoreductase}

When the membrane preparation was depleted of menaquinone by lyophilization followed by extraction with n-pentane, more than $90 \%$ of the NADH:fumarate oxidoreductase activity was lost in parallel with the loss of menaquinone (Table r). However, this was not unequivocal evidence that menaquinone is involved as an electron transfer carrier since other important compounds such as lipoproteins could have been removed. Experiments 


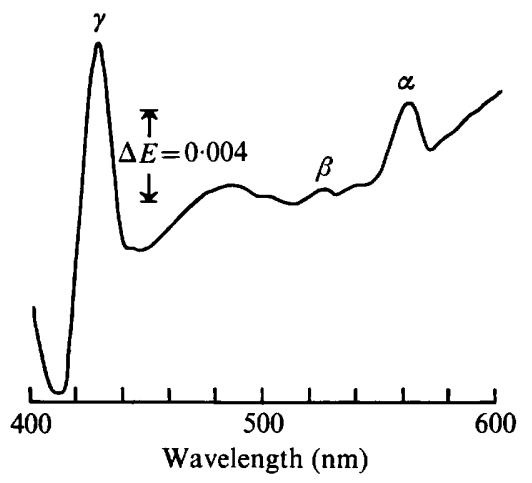

Fig. 3. Difference spectrum of $b$-type cytochrome in membrane particles. The experimental conditions used to oxidize the reference sample and reduce the experimental sample are described in Methods. Each cuvette contained $0.30 \mathrm{mg}$ protein $\mathrm{ml}^{-1}$.

were therefore carried out in which either menaquinone or vitamin $\mathbf{K}_{1}$ was reincorporated into quinone-depleted membranes. When n-pentane extract from $B$. ruminicola or commercial vitamin $\mathrm{K}_{1}$ was added to quinone-depleted membranes, $80 \%$ and $60 \%$, respectively, of the original NADH:fumarate oxidoreductase activity was restored, strongly suggesting that menaquinone is required for activity.

\section{Membrane-bound b-type cytochrome}

The presence of $b$-type cytochrome has previously been shown in whole bacteria (White et al., 1962). From the difference spectrum between dithionite-reduced and fumarateoxidized membrane preparations (Fig. 3), the concentration of $b$-type cytochrome in membranes was approximately $0.4 \mu \mathrm{mol}$ (g membrane protein $)^{-1}$, assuming a difference extinction coefficient $(557.5 \mathrm{~nm}$ minus $575 \mathrm{~nm})$ for cytochrome $b_{1}$ of $17.5 \mathrm{~mm}^{-1} \mathrm{~cm}^{-1}$ (Deeb \& Hager, 1964). In contrast, the concentration of $b$-type cytochrome in the supernatant fluid after centrifuging broken sphaeroplasts for $\mathrm{I} \mathrm{h}$ at $50000 \mathrm{~g}$, was $0.03 \mathrm{I} \mu \mathrm{mol}$ (g protein) $)^{-1}$ showing that the cytochrome was mainly present in the membrane fraction.

A difference spectrum between dithionite-reduced membrane preparations with and without carbon monoxide showed no peak at $4 \mathrm{I} 6 \mathrm{~nm}$ (data not shown), suggesting that no $o$-type cytochrome (Broberg \& Smith, 1967) having an affinity for carbon monoxide is present in strain $\mathrm{B}_{1} 4$. White et al. ( $\mathrm{I}_{962}$ ) reported a carbon monoxide difference spectrum similar to that of cytochrome $o$ in cells of $B$. ruminicola strain GA33 under strongly reduced conditions. This discrepancy is probably due to the difference in bacterial strains used.

\section{Reduction of b-type cytochrome under aerobic and anaerobic conditions}

The amount of $b$-type cytochrome reduced under various conditions can be measured from the absorbance difference at $427 \mathrm{~nm}$ minus $440 \mathrm{~nm}$ between a fumarate-oxidized membrane preparation and a reduced preparation. Taking the value for $b$-type cytochrome reduction in a preparation degassed under $\mathrm{N}_{2}$ and reduced by dithionite as $100 \%$ (data not shown), the amounts of $b$-type cytochrome reduced (i) by dithionite under aerobic conditions, (ii) by NADH under aerobic conditions, and (iii) by NADH under anaerobic (degassed) conditions, were 96,68 and $82 \%$ respectively. These results suggest that not all the $b$-type cytochrome is accessible to reduction by NADH. [This interpretation depends on the assumption that the single absorption band seen at room temperature is not a composite of 


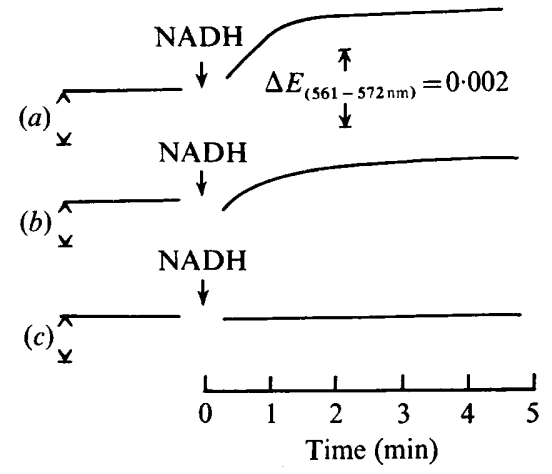

Fig. 4

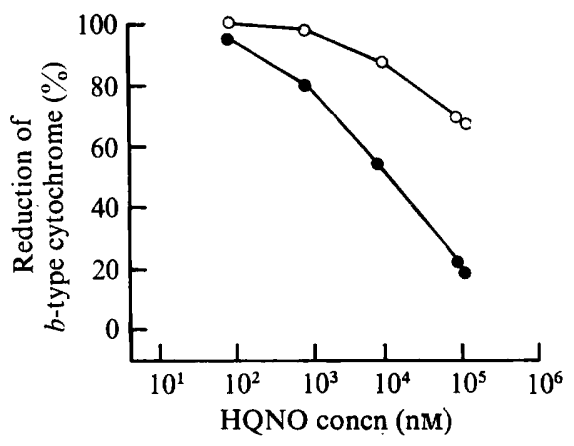

Fig. 5

Fig. 4. Reduction of $b$-type cytochrome by NADH in membrane particles. Activity was measured as the absorbance difference at $56 \mathrm{r} \mathrm{nm}$ minus $572 \mathrm{~nm}$ in membrane preparations using standard anaerobic incubation conditions. Each reaction was started by injecting $5 \mu$ mol fumarate $(\mathrm{c} \cdot \mathrm{I} \mathrm{ml})$ into the reference cuvette and an equal volume of water anaerobically into the experimental cuvette. The increase in absorbance is indicated by the arrowheads at $(a),(b)$ and $(c)$. Two minutes later NADH $(0.64 \mu \mathrm{mol})$ was injected into the experimental cuvette: (a) lyophilized membrane preparation $\left(0.76 \mathrm{mg}\right.$ protein $\left.\mathrm{ml}^{-1}\right) ;(b)$ membrane preparation depleted of quinone and subsequently reincorporated with menaquinone from $B$. ruminicola $\left(0.75 \mathrm{mg}\right.$ protein $\left.\mathrm{ml}^{-1}\right)$; $(c)$ membrane preparation depleted of quinone $\left(0.72 \mathrm{mg}\right.$ protein $\left.\mathrm{ml}^{-1}\right)$.

Fig. 5. Steady-state reduction of $b$-type cytochrome by NADH in the presence of HQNO. Membrane particles $\left(0.27 \mathrm{mg}\right.$ protein $\left.\mathrm{ml}^{-1}\right)$ were incubated in the standard incubation medium. NADH $(0.64 \mu \mathrm{mol})$ was added to the experimental cuvette and fumarate $(5 \mu \mathrm{mol})$ to the reference cuvette. When the $b$-type cytochrome reduction had reached a maximum, HQNO $(0.05 \mathrm{ml})$ dissolved in ethanol was injected into the experimental cuvette and the $56 \mathrm{I} \mathrm{nm}$ minus $572 \mathrm{~nm}$ absorbance difference was measured when the cytochrome re-oxidation reached a steady state. The reduction of $b$-type cytochrome $\left(\Delta E_{561 \mathrm{~nm}}-\Delta E_{572 \mathrm{~nm}}\right)$ is expressed as a percentage of the reduction found in the absence of HQNO. (O) Anaerobic conditions; (O) aerobic conditions.

several different pigments (cf. Shipp, 1972)]. Such differences between dithionite-reduced and NADH-reduced preparations are similar to the results of de Vries, van Wyck-Kapteyn \& Stouthamer (1973) and Schwartz \& Sporkenbach (1975) for Propionibacterium.

\section{Role of quinone in reduction of b-type cytochrome by NADH}

The $b$-type cytochrome of a lyophilized suspension of membrane particles was reduced by NADH at a rate of $0.175 \mu \mathrm{mol} b$-type cytochrome $\min ^{-1}$ (g protein) ${ }^{-1}$ (Fig. $4 a$ ). When the lyophilized membrane particles were extracted with $\mathrm{n}$-pentane to remove the quinone, the $b$-type cytochrome was reduced at less than $3 \%$ of the rate in unextracted particles (Fig. 4c). However, reincorporation of menaquinone into the depleted particles restored the electron transport capability between NADH and $b$-type cytochrome to $60 \%$ of the rate attained with unextracted particles (Fig. $4 b$ ). In another experiment (results not shown), reincorporation of vitamin $\mathrm{K}_{1}$ into depleted particles restored $40 \%$ of the rate attained with unextracted particles. These results suggest that the menaquinone is an intermediate in the process.

\section{Effect of oxygen and $H Q N O$ on b-type cytochrome reduction}

The results for $b$-type cytochrome reduction by NADH under aerobic and anaerobic conditions suggest that, under aerobic conditions in vitro, oxygen can be a terminal electron acceptor for the cytochrome. To confirm this, and at the same time investigate the site of HQNO inhibition, the steady-state reduction of $b$-type cytochrome by NADH was 
studied aerobically and anaerobically in the presence of different concentrations of HQNO (Fig. 5). Under both conditions the fraction of $b$-type cytochrome in the reduced form decreased as more HQNO was added, indicating that the site of HQNO inhibition was between NADH and the $b$-type cytochrome. The steady-state oxidation was greater under aerobic conditions than under anaerobic conditions, as would be expected if oxygen could act (under in vitro conditions) as terminal electron acceptor.

\section{Rate of b-type cytochrome reduction by NADH}

This was measured anaerobically in a typical preparation of unlyophilized membrane particles, using experimental conditions similar to those in Fig. $4 a$. In the absence of HQNO, the rate of $b$-type cytochrome reduction was $0.20 \mu \mathrm{mol} \mathrm{m^{-1 }}$ (g protein) $^{-1}$ [NADH:fumarate oxidoreductase activity in the same preparation was $15.5 \mu \mathrm{mol} \mathrm{m^{-1 }}$ (g protein $)^{-1}$. The rate of $b$-type cytochrome reduction by NADH was $70 \%$ and $95 \%$ inhibited by 4.3 and 43 nM-HQNO respectively [i.e. $4 \cdot 8$ and $48 \mu \mathrm{mol} \mathrm{HQNO}$ (g protein) ${ }^{-1}$ respectively]. Comparison with Fig. I (in which the rate was $15 \%$ and $65 \%$ inhibited by these inhibitor to protein ratios) indicates that electron transfer from NADH to $b$-type cytochrome is more sensitive to HQNO than electron transport from NADH to fumarate; this difference would appear even greater if HQNO had been expressed as concentration rather than as $\mu$ mol HQNO (g protein) ${ }^{-1}$.

In all three experiments above, anaerobic addition of fumarate to the particles, once $b$-type cytochrome reduction had reached a plateau, caused complete re-oxidation of the $b$-type cytochrome at a rate that was too fast to measure accurately.

\section{DISCUSSION}

The inhibitory effects of HQNO and the extraction experiments suggest that menaquinone is an intermediate carrier of reducing equivalents in the $\mathrm{NADH}$ : fumarate oxidoreductase reaction. The extraction of quinone from the membranes abolished not only NADH: fumarate oxidoreductase, but also the reduction of $b$-type cytochrome by NADH; and readdition of either extracted quinone or vitamin $\mathrm{K}_{1}$ restored these reactions to $40 \%$ or more of the original rate indicating that quinone is an intermediate in both. The involvement of menaquinone in electron transfer reactions is not unexpected since many Bacteroides species require added vitamin $\mathrm{K}$ for growth.

When $b$-type cytochrome is present in a succinate- or propionate-producing anaerobe, there is some doubt as to whether it is always an intermediate in the reduction of fumarate by NADH (Schwartz \& Sporkenbach, 1975). Our data indicate that the reaction between NADH and oxidized $b$-type cytochrome is much slower than that between reduced cytochrome and fumarate. Consequently, in the reactions in which $b$-type cytochrome and fumarate are reduced by $\mathrm{NADH}$, if the former were rate-limiting in the latter, one might expect the two reactions to have similar sensitivities to HQNO and to have similar overall rates. However, in the membrane preparation, HQNO inhibited $b$-type cytochrome reduction much more than fumarate reduction and the latter was 80 times faster. Thus it is difficult to include $b$-type cytochrome on the main electron transfer pathway between NADH and fumarate in the membrane preparation used, although as reduced $b$-type cytochrome is rapidly oxidized by fumarate, it is difficult to reconcile cytochrome having only a minor role in fumarate reduction. One possibility to be considered is that the reducing equivalents from, for example, pyruvate decarboxylation to acetate plus carbon dioxide or from formate oxidation, could pass through the cytochrome but the 


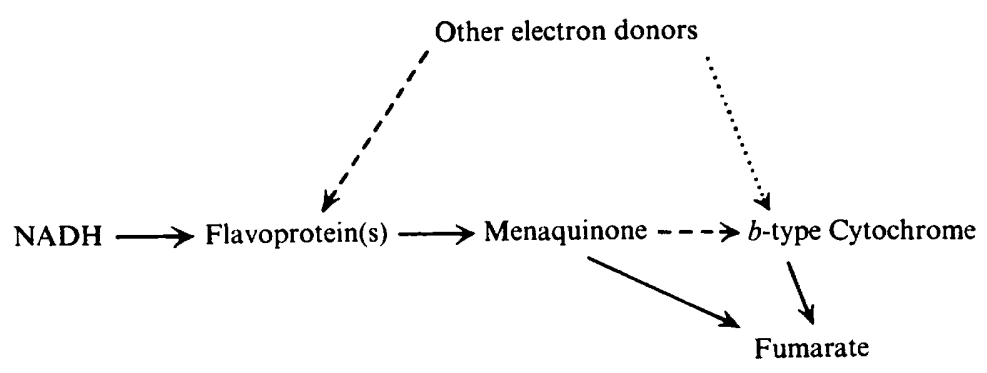

Fig. 6. Tentative scheme for the proposed electron transport pathway in the membrane fraction of $B$. ruminicola. Main pathway (-), minor pathway $(---)$, theoretical pathway yet to be investigated $(\cdots \cdot \cdots)$.

reducing equivalents from NADH may not. There are no published studies on pyruvate catabolism in Bacteroides, but in $E$. coli pyruvate and formate are important physiological electron donors to cytochrome $b_{1}$ (see Deeb \& Hager, 1964, for a summary). Another possibility which cannot be excluded is that during the preparation of membranes, the structure has been damaged in a manner such that $b$-type cytochrome is no longer on the main pathway. Chance (1952) found that such a phenomenon occurred during preparation of non-phosphorylating mitochondrial preparations.

In other Bacteroides species the need to include $b$-type cytochrome on the pathway of fumarate reduction is not clear. Bacteroides amylophilus lacks $b$-type cytochrome (Reddy \& Bryant, 1967), though growth yields are high and succinate is a major fermentation product (Hobson \& Summers, 1967). Macy et al. (1975) showed that B. fragilis changes from succinate to fumarate production in the absence of added haem, which gives rise to $b$-type cytochrome, and that NADH:fumarate oxidoreductase activity occurs in extracts from bacteria grown in the presence of haem but not in its absence. These results were interpreted as showing that $b$-type cytochrome is an intermediate in fumarate reduction by NADH. The role of $b$-type cytochrome in Propionibacterium species is also unclear. De Vries et al. (1973) have claimed that cytochrome $b$ is in the direct sequence of reactions leading to fumarate reduction. However, Schwartz \& Sporkenbach (1975) have presented evidence that cytochrome $b$ is a carrier in the pathway from NADH to oxygen but not fumarate.

From the available evidence, a tentative scheme for electron transport in B. ruminicola membranes is proposed (Fig. 6). Evidence for the role of flavoprotein is based on the observations of White et al. (1962) on whole bacteria and our own unpublished observations on membranes, that $\mathrm{NADH}$ reduces flavin and fumarate oxidizes flavin. The position of menaquinone and $b$-type cytochrome is based on the results in this paper. The pathway(s) from other electron donors, e.g. pyruvate, to fumarate remain to be investigated.

This investigation was supported by funds from the University Grants Committee of New Zealand, the Medical Research Distribution Committee of the Lottery Board of Control of New Zealand, and the Medical Research Council of New Zealand. The technical assistance of Mrs B. Harris is gratefully acknowledged. 


\section{REFERENCES}

Broberg, P. L. \& SMith, L. (1967). The cytochrome system of Bacillus megaterium KM. The presence and some properties of two CO-binding cytochromes. Biochimica et biophysica acta $\mathbf{1 3 1}, 479-489$.

Bryant, M. P., Small, N., Bouma, C. \& ChU, H. (1958). Bacteroides ruminicola n.sp. and Succinimonas amylolytica the new genus and species. Species of succinic acid-producing anaerobic bacteria of the bovine rumen. Journal of Bacteriology 76, 15-23.

ChANCE, B. (1952). Spectra and reaction kinetics of respiratory pigments of homogenised and intact cells. Nature, London 169, 21 5-22I.

Cox, G. B., Newton, N. A., Gibson, F., Snoswell, A. M. \& Hamilton, J. A. (1970). The function of ubiquinone in Escherichia coli. Biochemical Journal 117, 55 I-562.

Crane, F. L. \& Sun, F. F. (1972). Lipid and lipid-soluble compounds in electron transfer systems. In Electron and Coupled Energy Transfer in Biological Systems, vol. IB, pp. 477-587. Edited by T. E. King and M. Klingenberg. New York: Marcel Dekker.

DeEb, S. S. \& HAGER, L. P. (1964). Crystalline cytochrome $b_{1}$ from Escherichia coli. Journal of Biological Chemistry 239, I024-I03I.

Ernster, L., Lee, I. Y., Norling, B. \& Persson, B. (I969). Studies with ubiquinone-depleted submitochondrial particles. Essentiality of ubiquinone for the interaction of succinate dehydrogenase, NADH dehydrogenase and cytochrome b. European Journal of Biochemistry 9, 299-310.

Gornall, A. G., Bardawill, C. J. \& David, M. M. (I949). Determination of serum proteins by means of the biuret reaction. Journal of Biological Chemistry 177, 751-766.

Hobson, P. N. \& Summers, R. (1967). The continuous culture of anaerobic bacteria. Journal of General Microbiology 47, 53-65.

Howlett, M. R., Mountfort, D. O., Turner, K. W. \& Roberton, A. M. (1976). Metabolism and growth yields in Bacteroides ruminicola strain $\mathrm{B}_{14}$. Applied and Environmental Microbiology 32, 274-283.

KROGER, A. \& DADAK, V. (1969). On the role of quinones in bacterial electron transport. The respiratory system of Bacillus megaterium. European Journal of Biochemistry II, 328-340.

Kroger, A., DAdAK, V., KLINGenberg, M. \& Diemer, F. (I971). On the role of quinones in bacterial electron transport. Differential roles of ubiquinone and menaquinone in Proteus rettgeri. European Journal of Biochemistry 21, 322-333.

MACY, J., ProBSt, I. \& GotTSCHALK, B. (I975). Evidence for cytochrome involvement in fumarate reduction and ATP synthesis by Bacteroides fragilis grown in the presence of haem. Journal of Bacteriology 123 , 436-442.

MorTON, R. A. (1965). Spectroscopy of quinones and related substances. I. Ultraviolet absorption spectra. In Biochemistry of Quinones, pp. 23-65. Edited by R. A. Morton. New York and London: Academic Press.

ReDdy, C. A. \& BRyANT, M. P. (1967). DNA base composition and cytochromes in certain species of the genus Bacteroides. Bacteriological Proceedings, p. 40.

Schwartz, A. C. \& Sporkenbach, J. (1975). The electron transport system of the anaerobic Propionibacterium shermanii. Cytochrome and inhibitor studies. Archives of Microbiology 102, 261-273.

SHIPP, W. S. (1972). Absorption bands of multiple $b$ and $c$ cytochromes in bacteria detected by numerical analysis of absorption spectra. Archives of Biochemistry and Biophysics 150, 482-488.

DE VRIEs, W., van WyCk-Kapteyn, W. M. C. \& Stouthamer, A. H. (1973). Generation of ATP during cytochrome-linked anaerobic electron transport in propionic acid bacteria. Journal of General Microbiology 76, 3I-4I.

White, D. C., Bryant, M. P. \& Caldwell, D. R. (1962). Cytochrome-linked fermentation in Bacteroides ruminicola. Journal of Bacteriology 84, 822-828. 